\title{
BAGAIMANA RESPON PETANI MISKIN DI DUA DESA TEPI HUTAN, DI KECAMATAN UJUNG JAYA, KABUPATEN SUMEDANG PADA PRESENTASI AUDIO-VISUAL TENTANG CARA MEMBUAT KANDANG DOMBA YANG SEHAT?
}

\author{
Amri Jahi
}

\begin{abstract}
Abstrak
Menentukan respon para petani kecil, yang miskin, yang berdiam di desa-desa tepi hutan di Kecamatan Ujung Jaya, Kabupaten Sumedang pada presentasi audio-visual tentang cara membuat kandang domba yang sehat, perlu dilakukan. Hal ini penting untuk menentukan strategi pembelajaran yang tepat guna membantu para petani itu meningkatkan kapasitas mereka dalam mengelola sumberdaya alam di daerah itu. Penelitian ini merupakan bagian dari aktivitas penyuluhan untuk mengembangkan domba Garut di desa-desa tepi hutan itu. Penyuluhan bertujuan untuk mengembangkan sumberdaya manusia -- para petani -- agar supaya tahu, mampu dan mau bertindak secara arif dalam mengelola sumberdaya alam ditepi hutan untuk kemaslahatan hidup mereka. Domba ialah ruminansia kecil, yang hidup dari rumput dan daun-daunan yang banyak di daerah tepi hutan. Para petani yang memiliki cukup banyak domba akan memiliki cukup penghasilan, sehingga tidak perlu merambah hutan. Tahap awal beternak domba ialah membuat kandang yang memadai, kokoh dan sehat bagi domba. Kandang menaungi domba dari terpaan hujan, angin dan sengatan matahari. Kandang juga melindungi domba dari serangan predator. Kemudian, kandang menjadi tempat domba berkembang biak. Selanjutnya, pengandangan memudahkan petani memelihara dan merawat ternaknya. Penelitian ini bertujuan untuk menumbuhkan kesadaran para petani tentang pentingnya kandang yang baik, yang terbuat dari bahan-bahan setempat, yang berharga murah, untuk domba mereka. Selain itu, penelitian ini juga bertujuan untuk meningkatkan pengetahuan para petani itu tentang subyek penyuluhan ini. Untuk mencapai tujuan itu, sebuah program audio-visual berupa film slide bersuara didedahkan kepada dua kelompok petani pada saat pelatihan. Para petani itu dites sebelum dan sesudah didedahkan pada film slide bersuara itu. Hasil yang diperoleh menunjukkan bahwa kedua kelompok petani itu mendapat manfaat dari pendedahan itu. Pengetahuan mereka tentang berbagai aspek kandang domba dan cara membuatnya meningkat, walaupun secara statistik tidak nyata. Demikian juga dengan peningkatan pengetahuan kedua kelompok petani itu, tidak berbeda nyata. Hal ini terjadi karena ada persaingan stimuli audio dan visual dalam pengolahan informasi aural dan visual di benak para petani itu, yang menimbulkan efek saling tidak mengukuhkan. Namun demikian, para petani itu masih reseptif pada informasi tentang kandang domba yang baik, yang dipresentasikan pada mereka.
\end{abstract}

Kata Kunci: Desa Tepi Hutan, Program Audio-Visual, Strategi Pembelajaran, Penyuluhan, Kandang Domba, Domba Gaut, Peningkatan Pengetahuan

\section{Pendahuluan}

Sama seperti petani miskin lain, para petani kecil yang berdiam di desa-desa tepi hutanpun mendambakan aktivitas untuk menambah penghasilan. Salah satu aktivitas semacam ini yang diperkenalkan kepada para petani miskin di tepi hutan itu untuk memanfaatkan sumberdaya alam disekitar mereka ialah beternak domba. Domba yang diperkenalkan kepada para petani itu ialah domba Garut. Para petani miskin telah lama telah akrab dengan ternak ruminansia kecil ini. 
Paling tidak ada tiga manfaat yang dapat diperoleh para petani miskin, di desa Palasari dan Sukamulya, yang terletak ditepi hutan di Kabupaten Sumedang itu dari introduksi domba Garut. Yang pertama ialah para petani miskin di tepi hutan itu beroleh peluang untuk menambah penghasilan. Kedua, mereka dapat memanfaatkan rumput-rumputan dan daun-daunan yang banyak terdapat di tepi hutan sebagai pakan domba untuk menghasilkan produk-produk hewani yang bernilai tinggi, dan ketiga, dengan bertambahnya kesibukan memelihara domba dan tambahan penghasilan yang nyata, para petani itu akan turut menjaga kelestarian hutan disekitar desanya.

Studi kaji tindak ini dirintis pada pertengahan Maret 2003, sebagai perluasan dari aktivitas sejenis di Kabupaten Majalengka yang dirintis sejak tahun 1989. Kaji tindak di Majalengka itu pada mulanya didanai oleh International Development Research Centre (IDRC) dari Kanada. Dukungan keuangan dari donor internasional ini berakhir pada tahun 1995 (Jahi, 2001, $34)$.

Namun aktivitas pengembangan masyarakat di Kabupaten Majalengka masih berjalan terus, walau dalam skala dan kecepatan yang lebih rendah. Selama masih ada domba yang dikembalikan oleh para petani binaan, maka perguliran domba masih bisa dilakukan. Perluasan aktivitas ini ke Kabupaten Sumedang dimungkinkan karena ada sejumlah domba yang dapat digulirkan kembali.

Kontak dengan tokoh masyarakat di kecamatan Ujung Jaya dilakukan pada awal tahun 2003 melalui Haji Domon S. Parman almarhum. Pada mulanya aktivitas ini akan dilakukan sebagai percontohan di satu desa dulu dengan satu kelompok pemuda tani, yang terdiri dari sepuluh orang. Domba yang akan dipinjamkan kepada kelompok tersebut ialah sepuluh ekor dara yang telah masak tubuh dan dua ekor pejantan. Sebelum introduksi domba tersebut, para pemuda itu akan dilatih terlebih dahulu.
Pelatihan tersebut dilakukan pada 15 Maret 2003 di salah satu ruang serbaguna di Kecamatan Ujung Jaya. Namun yang datang ke pelatihan tersebut ternyata dua kelompok petani, campuran antara pemuda tani dan petani yang lebih tua. Kelompok pertama berasal dari desa Sukamulya dan kelompok kedua berasal dari desa Palasari.

Bagi peternak pemula, seluruh aspek beternak domba perlu dipelajari terlebih dahulu, termasuk cara membuat kandang domba yang baik, dengan biaya yang relatif murah. Hal inilah yang menyebabkan mengapa topik awal penyuluhan untuk membina para petani di kedua desa tepi hutan itu ialah tentang cara membuat kandang domba yang baik dan sehat.

Kandang ialah suatu komponen penting dalam proses produksi ternak domba. Bagi ternak, kandang ialah tempat tinggal dan berteduh dari terpaan air hujan, angin dingin di malam hari dan sengatan terik matahari di siang hari.

Selain itu, kandang juga melindungi ternak dari serangan predator dan pencurian. Kemudian kandang juga merupakan tempat bagi ternak untuk melakukan berbagai aktivitas seperti: istirahat, makan dan minum, membuang kotoran, kawin, beranak dan membesarkan anak (Merkel dan Subandriyo, 1997).

Sementara itu, bagi peternak, pengandangan penting untuk mengelola usaha-tani ternaknya dengan baik. Pengandangan memudahkan peternak memelihara dan merawat ternaknya. Ia dapat dengan mudah mengatur perkawinan ternaknya, memberi pakan yang sesuai dengan tingkat pertumbuhan ternaknya, dan menjaga kesehatan ternaknya. Pengandangan juga memudahkan peternak untuk memilih ternak mana yang sudah cukup dewasa untuk dijual dan ternak mana yang harus dipertahankan sebagai bibit.

Mengingat harga bahan bangunan yang semakin mahal, maka peternak pemula perlu mengetahui bahan-bahan bangunan apa saja yang dapat digunakan untuk 
membuat kandang yang kokoh, awet, mudah didapat di daerahnya dan berharga murah.

Sejalan dengan hal ini, penelitian ini, secara umum bertujuan untuk menumbuhkan kesadaran para petani tentang pentingnya kandang yang baik, yang terbuat dari bahanbahan setempat, yang berharga murah untuk domba-domba peliharaan mereka.

Secara khusus, studi ini bertujuan untuk: (1) menentukan perbedaan pengetahuan para petani tepi hutan itu tentang cara membuat kandang domba sebelum dan setelah didedahkan pada film bingkai bersuara tentang subyek tersebut, (2) menentukan apakah peningkatan pengetahuan yang dicapai oleh kedua kelompok petani yang dilibatkan dalam penelitian ini, setelah didedahkan pada presentasi audiovisual tentang cara membuat kandang domba itu berbeda,dan membandingkan tambahan pengetahuan yang didapat kedua kelompok tani itu bahasa Indonesia, yang direkam pada pita magnetik dalam sebuah kaset, untuk mendukung penayangan gambar-gambar tersebut dan menimbulkan efek-efek belajar tertentu.

Selain itu sebuah slide proyektor Kodak Carousel dan sebuah wireless sound system yang memiliki pemutar kaset, dipakai untuk mempresentasikan materi penyuluhan itu kepada khalayak sasaran yang dituju (Jahi, 2001, 40).

\section{Khalayak Sasaran}

Khalayak sasaran yang hendak dicapai pada studi penyuluhan ini ialah dua kelompok petani kecil tepi hutan yang miskin, yang hendak mengembangkan domba Garut di desa Palasari dan Sukamulya, kecamatan Ujung Jaya, kabupaten Sumedang.

Tabel 1 berikut ini mengungkapkan ukuran kedua kelompok petani, yang

Tabel 1. Besar kelompok yang Berpartisipasi pada presentasi film bingkai Bersuara tentang cara membuat kandang domba

\begin{tabular}{|c|c|c|}
\hline \hline Desa & Besar Kelompok & Persen \\
\hline \hline Palasari & 10 & 50 \\
\hline Sukamulya & 10 & 50 \\
\hline Jumlah & 20 & 100 \\
\hline
\end{tabular}

dengan tambahan pengetahuan yang didapat kelompok tani lain, yang pernah mengikuti tes serupa.

\section{Materi dan Metoda}

\section{$\underline{\text { Materi }}$}

\section{Materi Penyuluhan}

Materi penyuluhan yang digunakan dalam studi ini ialah sebuah program film bingkai (slide) bersuara yang berjudul "Bagaimana Membuat Kandang Domba yang Sehat." Film ini terdiri dari 63 bingkai gambar statis dan sebuah narasi dalam berpartisipasi dalam presentasi film bingkai bersuara tentang cara membuat kandang domba itu.

Tabel 1 di atas menunjukkan bahwa besar kedua kelompok petani tepi hutan dari kedua desa di kecamatan Ujung Jaya, yang berpartisipasi dalam kegiatan penyuluhan ini sebanding, masing-masing terdiri dari sepuluh orang.

\section{Desain Penelitian}

Desain dasar yang paling mendekati untuk pelaksanaan studi penyuluhan ini ialah 
salah satu dari tiga pre-experimental designs, yaitu, the One Group PretestPosttest Design (Campbell dan Stanley, 1966, h. 7-9). Dalam studi ini, design ini di ulang dua kali untuk meliput dua kelompok petani yang berdiam di dua desa itu. Menurut Campbell dan Stanley (1966, h. 7), desain ini masih banyak digunakan dalam penelitian pendidikan. Dalam studi ni ancaman pada validitas internal yang mungkin ditimbulkan oleh efek history dapat diatasi dengan jalan memberikan pretes, perlakuan dan postes dalam satu blok waktu. Waktu yang diperlukan untuk melaksanakan studi ini relatif singkat. Sehingga peluang timbulnya intervensi atau gangguan dari halhal yang tidak dapat dikendalikan diantara pretes dan postes dapat diminimalkan. Jadi, efek atau pengaruh film bingkai bersuara tentang cara membuat kandang domba pada postes akan terjadi tanpa gangguan.

\section{Data dan Instrumentasi}

Dua macam data yang diperlukan untuk mencapai tujuan penelitian ini ialah data pretes dan postes. Untuk mengumpulkan kedua macam data itu, dibuatlah sebuah instrumen tes yang terdiri dari 30 butir pernyataan yang benar atau salah.

Instrumen itu digunakan untuk mengukur pengetahuan kedua kelompok petani itu, tentang berbagai aspek kandang domba, sebelum dan sesudah didedahkan pada film bingkai bersuara tentang subyek tersebut.

\section{Uji Coba Instrumen Tes}

Instrumen yang digunakan untuk mengukur pengetahuan para petani tentang berbagai aspek kandang domba dan cara membuat kandang domba itu telah diuji coba terlebih dahulu untuk menentukan kesesuaiannya. Uji coba ini dilakukan pada tahap awal kegiatan lapangan penelitian pengembangan sistem produksi ternak domba, di salah satu desa di Majalengka. Uji coba ini melibatkan sepuluh orang petani kerjasama.
Seorang penyuluh yang telah dikenal baik oleh para petani kerjasama, membantu peneliti melakukan uji coba itu. Penyuluh tersebut menjelaskan maksud uji coba tersebut dan meminta para petani itu untuk memberikan respon pada seluruh butir instrumen yang dibacakan itu. Respon dan komentar penyuluh dan para petani itu digunakan untuk memperbaiki kalimatkalimat yang terdapat pada instrument tersebut.

\section{Pengumpulan Data}

Studi ini dilakukan pada minggu ketiga bulan Maret tahun 2003, menjelang introduksi domba Garut di kedua desa tersebut di atas. Kedua kelompok petani dari desa Palasari dan Sukamulya, kecamatan Ujung Jaya, Kabupaten Sumedang itu diundang untuk mengikuti pelatihan di ruang serbaguna Kecamatan Ujung Jaya, pada tangal 23 Maret 2003.

Sebelum acara dimulai, para petani itu diberi sarapan ringan berupa kopi dan kue-kue. Sesi riset ini berlangsung selama satu jam pada pagi hari tersebut. Setiap petani mendapat tempat duduk pada sebuah kursi, yang disusun mengikuti bentuk oval yang menghadap ke layar, instrumen tes, ballpen dan alas tulis portable, untuk membantu yang bersangkutan menuliskan responnya pada alat ukur itu.

Suasana pagi yang masih sejuk dan tenang di sekitar kantor kecamatan Ujung Jaya itu dan para petani yang masih segar, memungkinkan mereka mengikuti sesi riset dan pelatihan itu dengan tenang dan dapat berkonsentrasi dengan baik pada sesi pagi hari itu.

Sebelum pengumpulan data dimulai, penyuluh menjelaskan terlebih dahulu maksud pertemuan tersebut dan memberi petunjuk tentang cara mengisi jawaban pada pernyataan-pernyataan yang diajukan. Setelah itu pretes dilakukan. Untuk memperlancar pretes, penyuluh membacakan setiap butir pernyataan dan memberi kesempatan kepada para petani itu untuk memilih jawaban yang benar. 
Setelah selesai pretes, film bingkai bersuara tentang cara membuat kandang domba dipresentasikan kepada kedua kelompok petani itu. Segera setelah pertunjukan ini selesai, maka dilakukan postes dengan bimbingan penyuluh tersebut.

Jumlah waktu yang digunakan untuk seluruh aktivitas itu mencapai sekitar 60 menit. Lima menit pertama digunakan untuk pengantar dan penjelasan, kemudian 15 menit untuk presentasi film bingkai bersuara dan masing-masing 20 menit untuk pretes dan postes.
Data tambahan pengetahuan ini didapat dari selisih skor postes dan pretes milik setiap petani yang berpartisipasi dalam presentasi film bingkai bersuara tentang cara membuat kandang domba itu.

\section{Hasil dan Diskusi}

$\underline{\text { Hasil }}$

1. Pengaruh Film Bingkai Bersuara tentang Cara Membuat Kandang

Domba yang Sehat pada Pengetahuan Petani

Tabel 2. Skor pretes dan postes para petani tepi hutan tentang kandang domba

\begin{tabular}{ccc}
\hline \hline No & Skor Pretes & Skor Postes \\
\hline \hline 1 & 83,33 & 96,67 \\
2 & 90,00 & 96,67 \\
3 & 90,00 & 100,00 \\
4 & 83,33 & 96,67 \\
5 & 80,00 & 86,67 \\
6 & 76,67 & 93,33 \\
7 & 73,33 & 73,33 \\
8 & 70,00 & 80,00 \\
9 & 60,00 & 70,00 \\
10 & 76,67 & 86,67 \\
11 & 66,67 & 73,33 \\
12 & 76,67 & 66,67 \\
\hline \hline Rata-rata & 77,23 & 85,00 \\
\hline
\end{tabular}

$\begin{array}{llll}\text { df } \quad: 11 & \text { t critical two tail } & : 0.003 \\ \text { t Stat } \quad: 2.3 & \text { Pearson } \mathrm{r} & : 0.81 \\ \mathrm{P}(\mathrm{T}<=\mathrm{t}) & \text { two tail } & : \quad 0.05 & \end{array}$

\section{$\underline{\text { Analisis Data }}$}

Pertama, data pretes dan postes kedua kelompok petani itu dianalisis secara bersama-sama, dengan memakai Student $t$ Test, Paired Two sample for Means Procedure (Hopkins dan Glass, 1978, h. 233-234).

Kedua, data tambahan pengetahuan kedua kelompok petani itu dianalisis dengan menggunakan prosedur statistik $t$-Test: Two Sample Assuming Unequal Variances (Hopkins dan Glass, 1978, h. 251-252).
Tepi Hutan

Pengaruh pendedahan film bingkai bersuara tenatng cara membuat kandang domba yang sehat pada pengetahuan petani dapat dilihat pada Tabel 2 berikut ini.

Tabel 2 menunjukkan bahwa ratarata skor pretes dan postes yang diperoleh para petani yang dilibatkan dalam penelitian ini tidak berbeda nyata. Hal ini ditunjukkan oleh nilai t hitung sebesar 0,003 yang jauh lebih kecil dibandingkan dengan t Tabel, pada taraf nyata 0.05 . Nilai $t$ ini 
menunjukkan bahwa sekalipun ada peningkatan skor postes sebesar hampir delapan poin dari skor pretes, namun peningkatan skor ini masih kurang besar untuk menimbulkan perbedaan yang nyata diantara pretes dan postes.

2. Pengaruh Film Bingkai Bersuara tentang Cara Membuat Kandang

Domba pada Peningkatan Pengetahuan Petani

Pengujian kedua yang dilakukan pada hasil belajar para petani tepi hutan itu berpartisipasi dalam kegiatan penelitian penyuluhan ini. Data tambahan pengetahuan kedua kelompok petani ini dapat dilihat pada Tabel 3.

Tabel 3 di atas menunjukkan bahwa rata-rata peningkatan pengetahuan yang dicapai oleh kelompok petani Palasari dan Sukamulya tentang cara membuat kandang domba ialah 3,17 dan 1,5. Analisis lanjutan yang dilakukan pada kedua data ini mengunjukkan bahwa secara statistik, kedua skor peningkatan pengetahuan itu tidak berbeda nyata. Hal ini ditunjukkan oleh nilai

Tabel 3. Tambahan pengetahuan dua kelompok petani tepi hutan tentang kandang domba

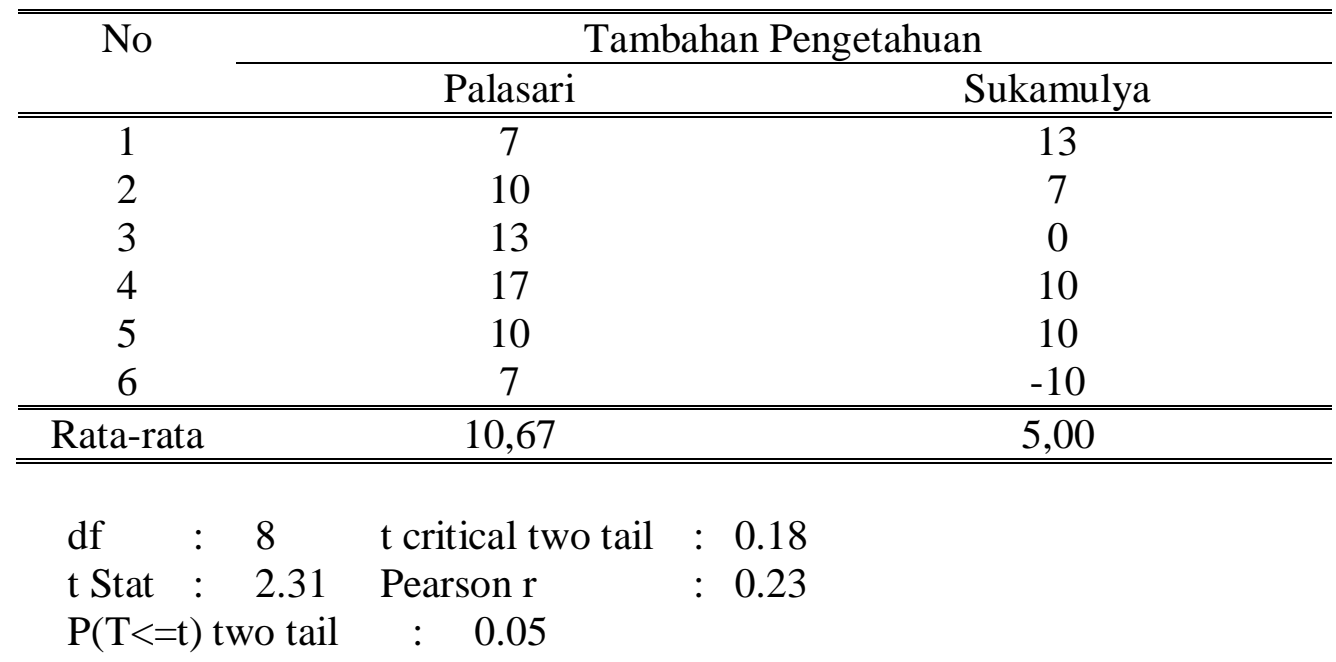

bertujuan untuk menentukan apakah ada perbedaan tambahan pengetahuan yang dicapai oleh kedua kelompok petani yang t hitung yang lebih kecil dari t table pada taraf nyata 0.05

3. Perbandingan Tambahan Pengetahuan dua

Tabel 4. Tambahan pengetahuan empat kelompok tani di Kabupaten Sumedang dan majalengka

\begin{tabular}{cccc}
\hline \hline \multicolumn{4}{c}{ Skor Tambahan Pengetahuan } \\
\hline \multicolumn{2}{c}{ Kabupaten Sumedang } & \multicolumn{2}{c}{ Kabupaten Majalengka } \\
\hline \hline Palasari $(\mathrm{n}=6)$ & Sukamulya $(\mathrm{n}=6)$ & Ciomas $(\mathrm{n}=24)$ & Kawung Girang $(\mathrm{n}=23)$ \\
\hline 7,00 & 13,00 & 17,00 & 22,00 \\
10,00 & 7,00 & 13,00 & 0 \\
13,00 & 0 & 9,00 & 9,00 \\
$\cdot$ & $\cdot$ & $\cdot$ & $\cdot$ \\
$\cdot$ & $\cdot$ & $\cdot$ & $\cdot$ \\
$\cdot$ & $\cdot$ & $\cdot$ & $\cdot$ \\
17,00 & 10,00 & $-9,00$ & $\cdot$ \\
10,00 & 10,00 & 0 & 13,00 \\
7,00 & $-10,00$ & 0 & $-14,00$ \\
\hline \hline 10,67 & 5,00 & 3,26 & 2,65 \\
\hline \hline
\end{tabular}


Kelompok Tani di Kabupaten

Sumedang dan dua Kelompok Tani di Kabupaten Majalengka

Hasil penelitian tentang tambahan pengetahuan yang diperoleh empat kelompok petani yang telah didedahkan pada film bingkai bersuara tentang cara membuat kandang domba yang sehat di kabupaten Sumedang dan Majalengka (Jahi, 2001, 40) dapat dilihat pada Tabel 4 berikut ini.

Tabel 4 menunjukkan urutan besar rata-rata skor tambahan pengetahuan tentang cara membuat kandang domba ialah sebagai berikut: yang terbesar dicapai oleh kelompok tani Palasari, kemudian oleh kelompok tani Sukamulya, berikutnya oleh kelompok tani Ciomas dan yang terkecil oleh kelompok tani Kawung Girang.

Secara statistik, rata-rata skor tambahan pengetahuan tentang cara membuat kandang domba kedua pasang kelompok tani di dua kabupaten ini tidak berbeda nyata.

\section{Diskusi}

Data yang dikemukakan pada Tabel 2 menunjukkan bahwa Rata-rata skor pretes yang dicapai oleh kedua kelompok tani petani tepi hutan tentang subyek penyuluhan cara membuat kandang domba ialah 77, 23, Sedangkan rata-rata skor postes yang mereka capai ialah 85 . Jadi ada peningkatan skor sebesar hampir delapan point.

Data pretes ini menunjukkan bahwa pengetahuan kedua kelompok petani itu tentang berbagai aspek kandang domba itu relatif tinggi. Artinya banyak hal yang telah mereka ketahui tentang subyek ini. Jadi, wajar bila presentasi audiovisual tentang cara membuat kandang domba yang sehat ini sedikit saja meningkatkan pengetahuan kedua kelompok petani itu.

Namun, pertanyaan yang timbul dari data yang diungkapkan oleh Tabel 2, 3 dan 4 itu ialah: "Mengapa skor pretes dan postes maupun skor tambahan pengetahuan yang dicapai oleh kedua pasang kelompok tani di dua kabupaten itu secara statistik tidak berbeda nyata?"

Jawaban yang mungkin ditawarkan pada pertanyaan tersebut di atas mungkin ditunjukkan oleh gradasi peningkatan tambahan pengetahuan yang dicapai oleh kedua pasangan kelompok tani itu. Tidak banyak diantara para petani itu yang memperoleh tambahan pengetahuan di atas 10 point. Beberapa diantara mereka skor postesnya, bahkan tidak bertambah atau malahan menjadi lebih kecil dari skor pretesnya. Hal inilah yang dapat ditawarkan sebagai jawaban pada pertanyaan di atas.

Tentang mengapa hal tersebut terjadi, penjelasan yang ditawarkan oleh Moreno (2001) dan Mayer dan Moreno (2000) tentang adanya prinsip auditory split attention. Menurut teori kognitif tentang belajar multimedia, warga belajar mengolah pesan-pesan multimedia dalam saluran visual dan audio yang kapasitasnya terbatas. Dalam kasus animasi bersuara, animasi diproses dalam saluran visual dan narasi diproses dalam saluran audio. Jika ada informasi audio tambahan, misalnya, dalam bentuk musik, maka pesan tambahan ini akan bersaing dengan narasi. Jika musik dan suara itu diolah dalam saluran yang kapasitasnya terbatas itu, maka kapasitas yang tersisa untuk memperhatikan narasi, mengorganisasikan narasi tersebut menjadi untaian sebab dan akibat yang koheren, dan menghubungkannya dengan pesan visual yang menyertai narasi tersebut akan semakin kecil (Moreno, 2001). Boleh jadi, persaingan antar ketiga macam pesan inilah yang menyebabkan buruknya hasil postes yang didapat oleh para petani itu.

\section{Kesimpulan}

Berdasarkan hasil yang diperoleh dan uraian tersebut di atas, maka dapat disimpulkan bahwa kedua kelompok petani miskin tepi hutan itu, setelah didedahkan pada presentasi audiovisual tentang cara membuat kandang domba yang sehat:

1. tumbuh kesadaran mereka tentang manfaat kandang domba yang baik. 
2. pengetahuan mereka tentang berbagai aspek kandang domba, termasuk tentang cara pembuatannya bertambah.

3. tambahan pengetahuan yang mereka peroleh tentang berbagai aspek kandang domba itu tidak berbeda.

\section{Rujukan}

Campbell, Donald T. and Julian C. Stanley. Experimental and Quasi Experimental Designs for Research. Chicago: Rand MacNally College Publishing Co., 1966.

Hopkins, Kenneth D. and Gene V. Glass. 1978. Basic Statistics for the Behaviortal Sciences. Englewood Cliffs, New Jersey: Prentice Hall Inc., 1978.

Amri Jahi. "Pengaruh Pengkomunikasian Cara Membuat Kandang Domba yang Sehat pada Peningkatan Pengetahuan Peternak Domba Garut di Desa Ciomas dan Kawung Girang, Kabupaten Majalengka, Jawa Barat." Media Peternakan 24 (Desember 2001): 39-44.

Merkel, Roger C. dan Subandriyo, eds. Sheep and Goat Production Handbook for Southeast Asia. $3^{\text {rd }}$ ed. Jakarta: Small Ruminant Collaborative Research Support Program, University of CaliforniaDavis, CA and Agency for Agricultural Research and Development, 1997.

Moreno, Roxana. "Designing for Understanding: A Learner-Centered Approach to Multimedia Learning." Albuquerque: Department of Educational Psychology, University of New Mexico, 2001.

Mayer, Richard E. and Roxana Moreno. "A Cognitive Theory of Multimedia Learnig: Implications for Design Principles." Santa Barbara: University of California, 2000. 